\title{
Reactive transport modelling of ore mineral zoning and the paragenesis of copper sulfides in sediment-hosted stratiform ore deposits, the Katanga Copperbelt (DRC)
}

\author{
PhILIPPE MUCHEZ1 \& Mercé CORBELLA²
}

${ }^{1}$ KU Leuven, Geofluids \& Geodynamics Research Group, Department of Earth \& Environmental Sciences, Celestijnenlaan 200E, B-3001 Leuven,Belgium.Corresponding author: philippe.muchez@ees.kuleuven.be

${ }^{2}$ Departament de Geologia, Universitat Autònoma de Barcelona, Bellaterra, Spain; merce.corbella@uab.cat

ABSTRACT. Reactive transport modelling was carried out to simulate the transport and precipitation conditions of copper sulfide minerals in the sediment-hosted ore deposits of the Central African Copperbelt. The results illustrate the advancement of a mineral front due to the reaction of copper-rich fluids with host rocks. Chalcopyrite $\left(\mathrm{CuFeS}_{2}\right)$ initially precipitates in the reducing host rock and pyrite $\left(\mathrm{FeS}_{2}\right)$ dissolves, but the latter re-precipitates as a halo beyond the chalcopyrite. Continuous supply of copper causes the formation of the copper-rich sulfide bornite $\left(\mathrm{Cu}_{5} \mathrm{FeS}_{4}\right)$ followed by chalcocite $\left(\mathrm{Cu}_{2} \mathrm{~S}\right)$ with precipitation of chalcopyrite and pyrite further down the flow direction. Anhydrite disappears where both copper sulfides and pyrite are precipitated. The modelled sulfide paragenesis and the general distribution of these minerals correspond to patterns observed in rocks within the Katanga Copperbelt.

KEYWORDS: bornite, chalcocite, chalcopyrite, pyrite, anhydrite, Democratic Republic Congo, Mines Subgroup

\section{Introduction and geological setting}

Sediment-hosted stratiform copper deposits are characterized by including several types of sulfide and oxide minerals that exhibit different zoning and paragenesis. Stratiform copper mineralization in the Katanga Copperbelt (Democratic Republic of Congo; Fig. 1) took place in the Neoproterozoic Katanga Supergroup, mainly in the Roan Group, but also in the Nguba and Kundelungu Groups. The Nguba Group overlies the Roan Group and consists at its base of the Grand Conglomérat, a glacial deposit. The Nguba Group is overlain by the Kundelungu Group, with the Petit Conglomérat at its base. The latter is also a diamictite deposit (Cailteux et al., 2005). Two main ore bodies are present in the Mines Subgroup in the lower part of the Roan Group, i.e. the Lower and Upper Orebody. Between both ore bodies, a barren or weakly mineralized member, the Roches Siliceuses Cellulaire (RSC), occurs. The host rock of the two ore bodies is formed by dolomitic shales, siltstones and stromatolitic dolomites (Cailteux et al., 2005). The latter shales and siltstones contain lenticular layers and nodules of pseudomorphs after anhydrite and very early diagenetic pyrite (Cailteux et al., 2005). The RSC is interpreted to originally represent massive stromatolitic dolomites with some interbedded dolomitic siltstone, and thus biogenic carbonates.

Numerous ore deposit models have been proposed for the Katanga copper deposits during the last hundred years (for a review see Cailteux et al., 2005; Selley et al., 2005). A multiphase origin has been proposed by many authors during the last decade
(Cailteux et al., 2005, Selley et al., 2005; Dewaele et al., 2006; El Desouky et al., 2010), and is characterized by several hypogene phases, ranging from early diagenetic up to syn-orogenic, followed by an important supergene phase (Decrée et al., 2010; De Putter et al., 2010).

\section{Geological and geochemical constraints on copper mineralization}

The stratiform copper-cobalt deposits in the Katanga Copperbelt show a lateral variation from copper-rich zones to copper-poor and finally to pyritic and barren zones. Paragenetic studies indicate that pyrite, often present as framboids, was the first sulfide phase to precipitate with a lateral and vertical distribution well beyond the ore deposits (Bartholomé, 1963). This early pyrite was replaced by chalcopyrite (Bartholomé et al., 1972). At Kamoto and Luiswishi (Katanga Copperbelt), this replacement is followed by a general succession of chalcopyrite, bornitecarrollite and chalcocite (E1 Desouky et al., 2010). A vertical and lateral distribution pattern from copper-rich minerals (chalcocite) to pyrite has been described for many deposits in the Katanga Copperbelt (Oosterbosch, 1962; Lefebvre, 1989; Cailteux et al., 2005). Where sulfides occur as pseudomorph after evaporites in nodules and layers, a dominance of chalcocite, carrollite and bornite rather than chalcopyrite is observed at Kamoto (Muchez et al., 2008). In evaporitic sediments of the lower Roan Group early diagenetic dolomite was precipitated prior to copper sulfide formation (Cailteux et al., 2005). This dolomite is non-

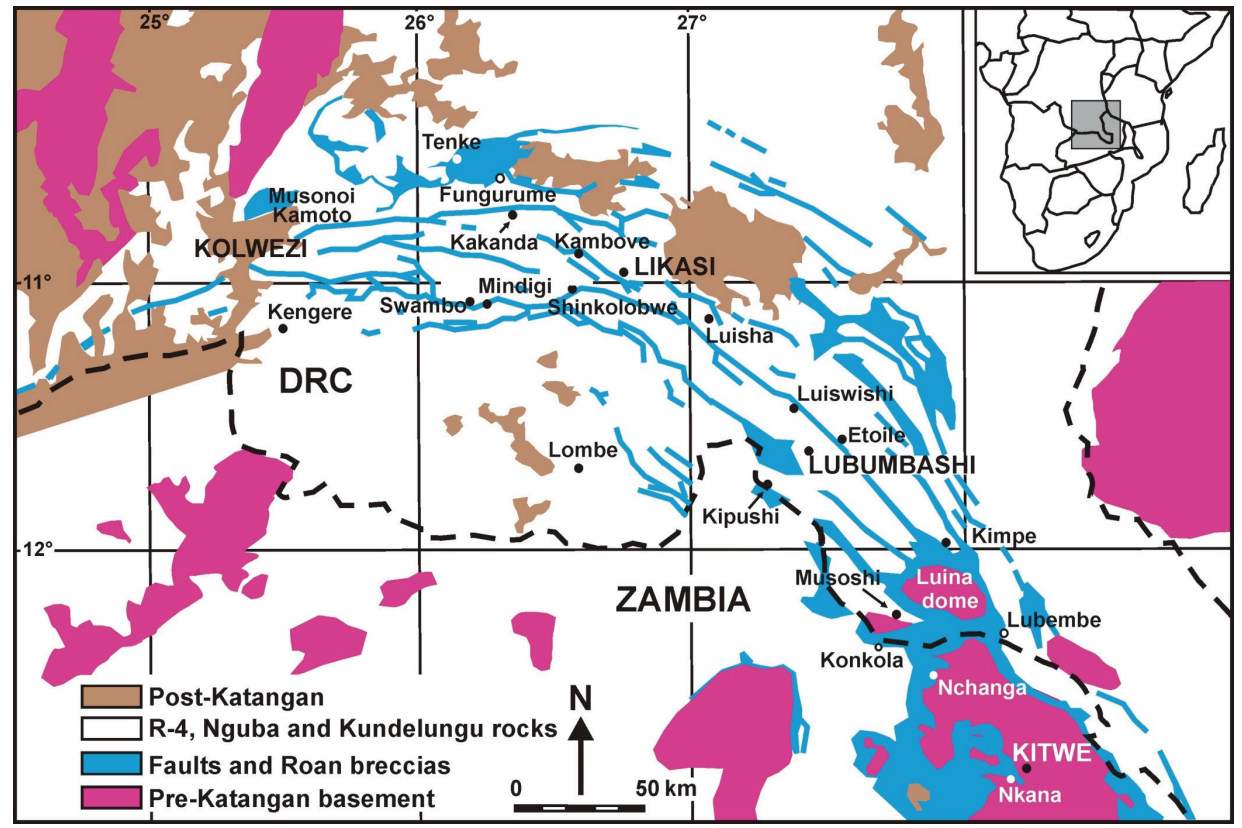

Figure 1. Location of the Central African Copperbelt and of the most important ore deposits (after Cailteux et al. 2005). 


\begin{tabular}{lll}
\hline & Formation water & Mineralizing fluid \\
\hline $\mathrm{Al}$ & $2.3810^{-07}$ & $6.4410^{-07}$ \\
$\mathrm{Ca}$ & $1.2810^{-02}$ & $4.0210^{-02}$ \\
$\mathrm{Cl}$ & 2.12 & 2.13 \\
$\mathrm{Cu}$ & $1.0010^{-09}$ & $1.5010^{-03}$ \\
$\mathrm{Fe}$ & $4.5010^{-06}$ & $4.4110^{-10}$ \\
$\mathrm{~K}$ & $3.9610^{-03}$ & $5.0510^{-02}$ \\
$\mathrm{Mg}$ & $2.0310^{-01}$ & $6.8610^{-03}$ \\
$\mathrm{Na}$ & 1.81 & 2.0010 \\
$\mathrm{~S}$ & $8.4910^{-02}$ & $2.3210^{-05}$ \\
$\mathrm{Si}$ & $1.9610^{-03}$ & $1.9810^{-03}$ \\
alkalinity & $5.3310^{-03}$ & $1.0310^{-02}$ \\
$\mathrm{pH}$ & 5.27 & 6.57 \\
$\mathrm{pe}$ & -1.70 & 7.00 \\
\hline
\end{tabular}

Table 1. Chemistry of formation water and mineralizing fluid at $150{ }^{\circ} \mathrm{C}$ (concentration of elements in $\mathrm{mol} / \mathrm{kg}$ ) (after Muchez \& Corbella, 2012).

luminescent under cathodoluminescence petrography (Dewaele et al., 2006). Authigenic quartz is intergrown with the sulfides and precipitated in rocks of the Lower and Upper Orebody and in the low-grade intermediate zone (Oosterbosch \& Schuiling, 1951; Bartholomé et al., 1972; Cailteux, 1994). This mineralization phase occurred around $800 \mathrm{Ma}$ at shallow to intermediate burial depth (Muchez et al., 2015).

The main phase of copper mineralization was followed by a second dolomitization phase which caused the recrystallization of the earlier dolomites and precipitation of digenite and chalcocite. These dolomites show a bright orange cathodoluminescence. Locally pyrite and chalcopyrite were recrystallized during this dolomitization (Dewaele et al., 2006). The samples investigated by Dewaele et al. (2006) from the Lower and Upper Orebody at Kamoto were largely devoid of pyrite and chalcopyrite which occur only above the Upper Orebody. The absence of chalcopyrite in the main orebodies has been explained due to the large amount of available copper (and less iron) resulting in the formation of bornite and chalcocite rather than chalcopyrite.

Fluid inclusion microthermometry showed that a first copperbearing fluid had a moderate salinity $(8.4-20.9$ eq. $w t \% \mathrm{NaCl})$ and temperature $\left(80-220^{\circ} \mathrm{C}\right.$; El Desouky et al., 2009; Muchez et al., 2008). The present study uses the characteristics of this mineralizing fluid. A second mineralizing fluid, which was present in the subsurface of the Katanga Copperbelt during late burial, metamorphism and orogenesis has a much higher temperature $\left(270-385^{\circ} \mathrm{C}\right)$ and salinity $(35-45.5$ eq. wt $\% \mathrm{NaCl}$; El Desouky et al., 2009). This mineralizing event was not modelled.

The aim of this study is to investigate the factors that control the paragenesis as well as the lateral and vertical distribution of the copper sulfide minerals and especially the evolution of this paragenesis and distribution through time in the stratiform $\mathrm{Cu}-\mathrm{Co}$ ore deposits in the Copperbelt. As an example for building the model the stratigraphy of the Tenke-Fungurume ore deposit has been taken, but the results and interpretation are equally valid for other, similar deposits in the DRC. The present paragenesis and distribution of the sulfide minerals can nicely be deduced from a detailed petrographic study, however, the evolution through time is only possible by applying a reactive transport model. This allows to determine the different stages in the sulfide mineralization through time. This study forms a continuation of the reactive transport modelling carried out by Muchez \& Corbella (2012). In the latter study, the authors studied the factors controlling the precipitation of copper and cobalt minerals in sediment-hosted deposits, with special emphasis on the Copperbelt. Based on an extensive literature study, they specified the thermodynamic properties for copper and iron in solution and the thermodynamic properties of copper and cobalt sulfides. Different reactions with different valence of the ions in solution have been applied. Based on the results of the reactive transport, they concluded that the most realistic results were obtained considering $\mathrm{Cu}^{+2}$ and $\mathrm{Fe}^{+2}$ in solution. Unfortunately, they were only able to simulate a period of 30,000 years and only observed a lateral variation in the ore sulfides. The 30,000 years simulation showed that the continuous supply of copper and cobalt causes the formation of more metalrich sulfides, i.e. a higher copper or cobalt to sulfide ratio. The cobalt minerals that could be simulated were cattierite $\left(\mathrm{CoS}_{2}\right)$ and linnaeite $\left(\mathrm{Co}_{3} \mathrm{~S}_{4}\right)$ which are minor minerals in the Copperbelt. The lack of thermodynamic data for carrollite $\left(\mathrm{CuCo}_{2} \mathrm{~S}_{4}\right)$ inhibited the study of the precipitation of the most important cobalt mineral in the Copperbelt. In the present study, the cobalt minerals were omitted allowing the modelling over a much larger period of time, i.e. 120,000 years. This modelling allows to obtain a more profound insight in the paragenesis and the lateral and vertical distribution of the iron and copper sulfides.

The geochemical simulator Phreeqc (Parkhurst \& Appelo, 1999) was used to calculate the fluid composition and speciation. Phreeqc contains different thermodynamic data files that can be used in the geochemical calculations. For modelling at higher temperatures $\left(150-300{ }^{\circ} \mathrm{C}\right)$ and in the presence of sulfides the database 1lnl.dat is the most appropriate. It was created by G. Anderson to include most of the aqueous species and minerals compiled by J. Johnson of the Lawrence Livermore National Laboratory, including more elements than the other databases. The results of the analyses of the fluid inclusions from the mineralization form the basic parameters, i.e. total salinity $(2.12$ $\mathrm{mol} / \mathrm{L}$ ) and temperature (El Desouky et al., 2009; Muchez et al., 2008) of the modelled fluids. The original source of the fluids was evaporated sea water of which the geochemistry was simulated with Phreeqc. In addition, this evaporated seawater equilibrated with the rocks in the subsurface within the region. Therefore, the modelling workflow consisted of simulating evaporation of sea water until a chloride content of $2.12 \mathrm{~mol} / \mathrm{L}$ in solution was reached. The saturation index (SI) of anhydrite was then equal to 0 . In a second step, fluid composition and speciation were simulated with Phreecqc, i.e. of the evaporated fluid in equilibrium with different types of rock at an average mineralization temperature of $150{ }^{\circ} \mathrm{C}$. The following rock compositions have been used: mafic (anorthite, enstatite, ferrosilite, forsterite, fayalite), granitic (albite, muscovite, quartz, K-feldspar, flogopite, annite) and sedimentary (quartz, illite, dolomite, anhydrite, pyrite). All resulting fluids had a strong reducing character $(\mathrm{pe}=-6.0)$ after reaction with the mafic rocks or with a combination of mafic and granitic rocks. But, as an oxidizing mineralizing fluid is generally accepted for the Copperbelt deposits (Hitzman et al., 2010), it is assumed this fluid should have also equilibrated with the red siliciclastic rocks that occur below the mineralized sequences. Therefore, the fluid was further equilibrated with hematite-hausmannite, acquiring a pe of +7.0 (Table 1; Muchez \& Corbella, 2012). The fluids compositions obtained with Phreeqc were subsequently used as starting solutions for the reactive transport model.

\section{Reactive transport modelling}

The reactive transport modelling has been carried out with the geochemical simulator Retraso (Saaltink et al., 1998), which couples multi-element transport in solution with chemical reactions from 0 to $300{ }^{\circ} \mathrm{C}$. The fluids compositions obtained with Phreeqc were used as starting solutions for the reactive transport models. The computer program Retraso (Reactive Transport of Solutes) takes into account complexes in aqueous solutions and the precipitation and dissolution of minerals, either at local equilibrium conditions or kinetic laws. Since kinetic rate laws for the sulfide minerals are often lacking, precipitation under equilibrium conditions were assumed for the sulfides. The standard thermodynamic database is that of EQ3/6 (Wolery, 1992; compiled by Peter Lichtner). The species considered are based on the most abundant species in the modelled fluid composition with Phreeqc. For copper, $\mathrm{Cu}^{+}, \mathrm{Cu}^{+2}, \mathrm{CuCl}_{3}^{-2}$ and $\mathrm{CuCl}_{2}^{-}$were used. The total copper content of $100 \mathrm{ppm}$ in the mineralizing solution 


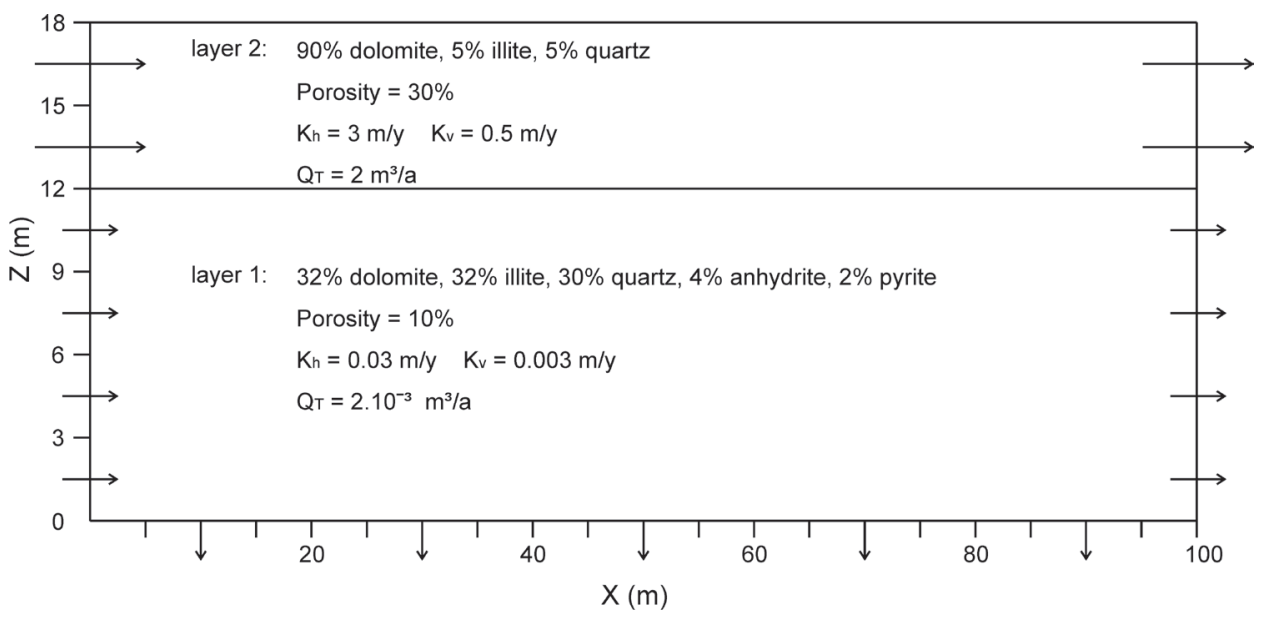

Figure 2. Physical and conceptual model for the reactive transport simulations consisting of two sedimentary layers, which reflect the barren Roches Siliceuses Cellulaires (RSC) overlying rocks of the Lower Orebody in the Katanga Copperbelt (after Muchez \& Corbella, 2012).
(Table 1) is mainly present as $\mathrm{CuCl}_{2}^{-}$and to a lesser extent as $\mathrm{CuCl}_{3}{ }^{-2}$.

The reactions taken into account for the precipitation of chalcopyrite, bornite and chalcocite are:

$\mathrm{Cu}^{+2}+\mathrm{Fe}^{+2}+2 \mathrm{HS}^{-}=\mathrm{CuFeS}_{2}(\mathrm{~s})+2 \mathrm{H}^{+}(1)$

$4 \mathrm{Cu}^{+}+\mathrm{Cu}^{+2}+\mathrm{Fe}^{+2}+4 \mathrm{HS}^{-}=\mathrm{Cu}_{5} \mathrm{FeS}_{4}(\mathrm{~s})+4 \mathrm{H}^{+}(2)$

$2 \mathrm{Cu}^{+}+\mathrm{HS}^{-}=\mathrm{Cu}_{2} \mathrm{~S}(\mathrm{~s})+\mathrm{H}^{+}(3)$

The modelled system consists of a rectangular section with two horizontal sedimentary layers, which reflect the Roches Siliceuses Cellulaires (RSC) overlying the mineralized dolomitic shales and siltstones and the silty dolomites of the Lower Orebody (Fig. 2; Muchez \& Corbella, 2012). The RSC forms the main conduit for the mineralizing fluid (Fay \& Barton, 2012). The Lower Orebody (layer 1) is $12 \mathrm{~m}$ thick and initially consists of $32 \%$ dolomite, $30 \%$ quartz, $32 \%$ illite, $4 \%$ anhydrite and $2 \%$ pyrite. A conservative value of $10 \%$ is taken for the porosity (Fig. 2; cf. Oosterbosch, 1962). Since the RSC forms the main aquifer of the fluid causing the mineralization of both the Lower and Upper Orebody, only half of the thickness of this aquifer has to be taken into account for modelling the mineralization in the Lower Orebody. So, the thickness of the RSC (layer 2) used in the modelling is $6 \mathrm{~m}$, half of the total thickness and the upper boundary of the system is taken in the middle part of the RSC member. The minerals originally present in layer 2 are $90 \%$ dolomite, $5 \%$ illite and $5 \%$ quartz. The initial porosity of this dominant carbonate rock is $\sim 30 \%$, certainly reasonable for a reef carbonate at shallow burial conditions (cf. Cailteux et al., 2005).

The grid used in the model is $100 \mathrm{~m}$ long, $18 \mathrm{~m}$ high and contains 273 nodes and 480 cells. The vertical dimensions of the cells vary from $1 \mathrm{~m}$ near the boundary between layer 1 and 2, to 2 $\mathrm{m}$ further away. The horizontal cell dimensions are kept constant at $10 \mathrm{~m}$. The flow model is based on the study of Fay \& Barton (2012). The most important lateral fluid migration took place in layer 2 and a flux of $1 \mathrm{~m} / \mathrm{y}$ is assumed for the reefal carbonate. A much smaller flux of $0.01 \mathrm{~m} / \mathrm{y}$ is considered in layer 1 consisting of a mixture of dolomite, quartz and clays (illite). The values used for the fluxes are reasonable when compared to the fluxes used in other reactive transport models applied to sediment-hosted $\mathrm{Zn}-\mathrm{Pb}$ deposits (Corbella et al., 2004). Flow boundaries are open to the right side of the inflow and at the bottom, to allow a lateral and a downward migration of the fluid from layer 2 at the top into layer 1. The total time modelled is 120,000 years requiring more than 10,000 simulation time steps.

\section{Results and interpretation}

Simulations are presented for time periods of $0,15,000,50,000$, 90,000 and 120,000 years (Fig. 3). These simulation times are chosen based on changes in ore mineral precipitation. Chalcopyrite is the first copper sulfide that precipitates in layer 1 right below the boundary with layer 2 . It starts forming immediately after the mineralizing fluid reaches the system, while pyrite and anhydrite dissolve and precipitate some meters below it (Fig. 3B). This observation can be regarded as the replacement of pyrite by chalcopyrite and the pseudomorphosis of anhydrite by chalcopyrite. No sulfides precipitate in layer 2. Chalcopyrite precipitation is followed by bornite formation in layer 1 at the margin with layer 2; bornite starts as a minor mineral approximately after $\sim 13,000$ years of simulation time, not appreciable in the plot. After $\sim 50,000$ years (Fig. 3C), chalcocite forms at the boundary between layers 1 and 2, where earlier chalcopyrite has been dissolved. Bornite is also dissolved from this zone with time, which could also suggest the replacement of both chalcopyrite and/or bornite by chalcocite.

After $\sim 90,000$ years of simulation time (Fig. 3D), a new mineralized zone of chalcopyrite develops near the inflow and below chalcocite, while it moves, together with bornite, further to the right in the top two meters of layer 1. Pyrite continues to dissolve in the upper part of layer 1 but forms a halo below the copper sulfides up to $6 \mathrm{~m}$ below the contact between layer 1 and 2 and which extends more and more in the flow direction.

After $\sim 120,000$ years, also bornite precipitates slightly below the chalcocite zone in layer 1, while the zone with chalcopyrite extends in the flow direction (Fig. 3E). The latter could be explained by a replacement of pyrite by chalcopyrite and of chalcopyrite by bornite in this horizon. At the top of layer 1, the zone with bornite moves further to the right and the zone with chalcocite increases, which could indicate the replacement of bornite by chalcocite. A horizontal and vertical zoning in the mineral distribution is also present. Near the contact with layer 2, chalcocite and bornite dominate and chalcopyrite and pyrite appear further away. A similar zoning can be observed in the flow direction.

\section{Discussion}

The simulated sulfide mineralization constitutes a mineralizing front that advances slowly, laterally and downwards, as a response to the reactions between a copper-rich fluid and host rock. This fluid is capable of dissolving host rock minerals such as anhydrite and pyrite, which give the fluid the capability of precipitating copper sulfides. Nevertheless, the same fluid has also the capacity of dissolving some of the earlier copper sulfides formed at the expense of precipitating richer copper sulfides, thus developing zones with different proportions of varied sulfides. Similar to other mineral fronts, the fluid flows much faster than the mostly lateral advance of the sulfide mineral zones. In such cases, the ore deposit is only preserved once the fluid has either ceased or is no longer mineralizing.

The paragenesis of the sulfides observed through the modelling is similar to the paragenesis independently proposed by many authors such as Dewaele et al. (2006) and Schuh et 

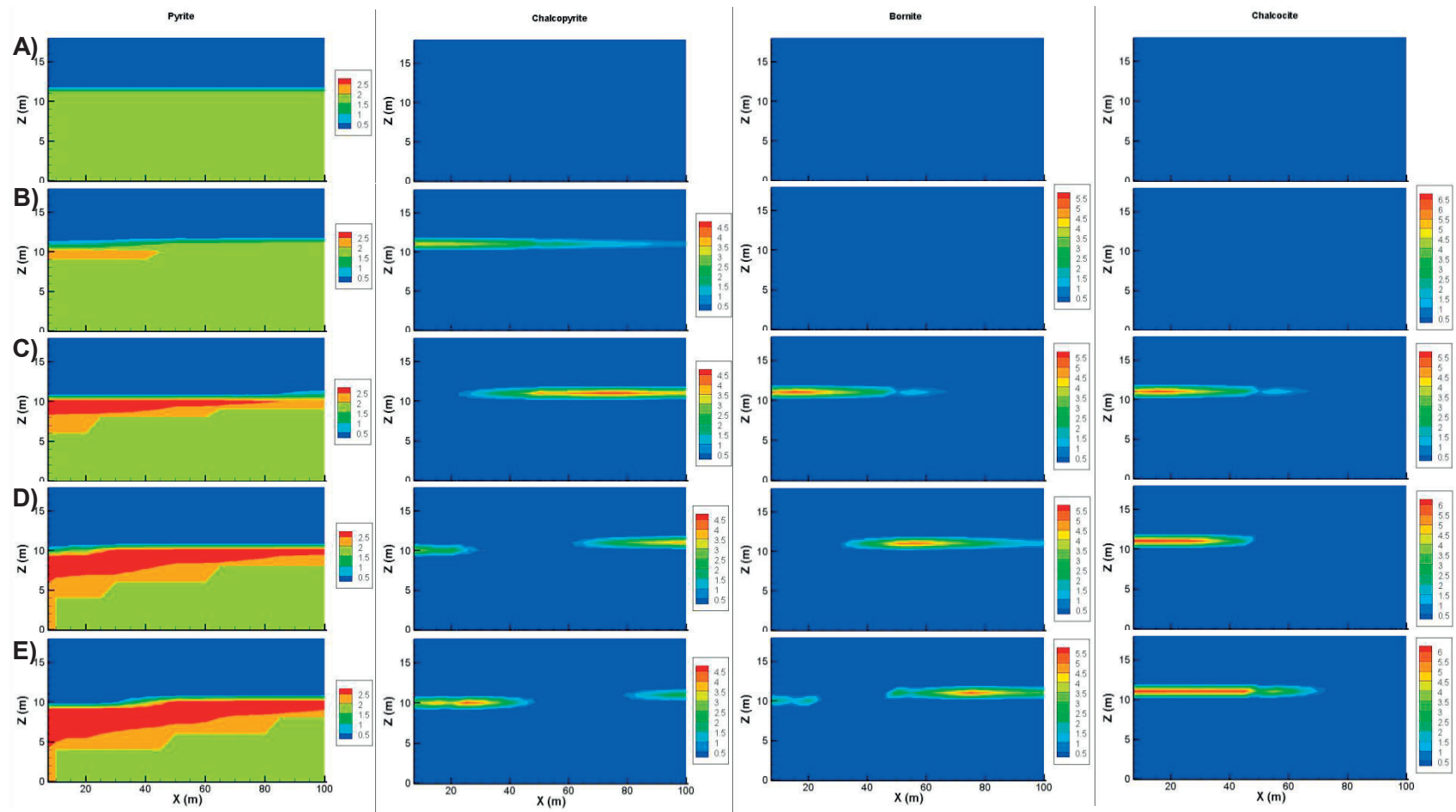

Figure 3. Evolution in time of the dissolution and precipitation of sulfide minerals (pyrite, chalcopyrite, bornite and chalcocite, $\%$ volume) as a result of reactive transport simulations.

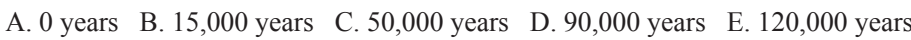

al. (2012) in the Katanga Copperbelt. The model simulates the often observed replacement of pyrite by chalcopyrite as a first process during mineralization (cf. Bartholomé et al., 1972). This replacement of pyrite by chalcopyrite is followed by the replacement of chalcopyrite by bornite, bornite by digenite and finally digenite by chalcocite (El Desouky et al., 2010). Chalcopyrite, bornite and chalcocite can also occur as direct precipitates or replacement of anhydrite in nodules and lenses (Muchez et al., 2008). The absence of pyrite and chalcopyrite in the orebodies observed at Kamoto by Dewaele et al. (2006) can be explained by the continuous supply of copper by an oxidizing (Fe-poor) fluid. The high-grade mineralization of the dolomitic shale at the contact with footwall, with a sharp cutoff at the contact and an exponential decrease upwards has been described by Annels (1989). Although we only show the most permeable layer above the mineralized zone, the results are the same in the reverse configuration with layer 2 as footwall rocks. A lateral and vertical zoning with copper-rich minerals followed by less copper-rich minerals and pyrite is characteristic in both the Katanga (Cailteux, 1994; Cailteux et al., 2005) and Zambian Copperbelt (Garlick, 1961; Lee-Potter, 1961; McKinnon \& Smit, 1961; Selley et al., 2005). The model nicely simulates the results of Van Langendonck et al. (2013), who described a vertical zoning of chalcocite to bornite, chalcopyrite and pyrite in the ore at Kambove West. The replacement of anhydrite by the sulfides, which is a characteristic feature of the stratiform ores both in the DRC and Zambia (Bartholomé et al., 1972; Annels, 1974; Cailteux, 1978), is reflected by the complete disappearance of anhydrite in the sulfide-mineralized parts.

The Lower Orebody is not as homogeneous as modelled in this study. It consists of an alternation of fine-grained dolomitic shales and dolomites and dolomitic siltstones and fine-grained sandstones (François, 1973). These laminae are of a few $\mathrm{mm}$ to $\mathrm{cm}$ thick. Sulfide mineralization typically occurs at the contact between these shales and the coarser-grained, quartz-rich laminae (Cailteux et al., 2005). This implies that lateral fluid flow was more important in layer 1 than assumed in this model, i.e. in the coarser-grained laminae. A simulation of ore precipitation on a $\mathrm{mm}$ - to $\mathrm{cm}$-scale in these laminae would be an interesting step in future modelling to obtain a more detailed insight in ore formation in the Copperbelt.

Recently, a detailed study of the alteration and mineralization of a stratiform copper deposit in the Katanga Copperbelt has been carried out by Schmandt et al. (2013). The ore deposit studied occurs at Kamoa and is not situated in the Mines Subgroup but in the uppermost part of the Mwashya Subgroup and the Grand Conglomérat Subgroup of the Nguba Group (Broughton \& Rogers, 2010). Based on detailed petrography combined with QEMSCAN analyses Schmandt et al. (2013) found an upward zoning in the ore mineralogy from chalcocite to bornite, chalcopyrite, pyrite in the Grand Conglomérat. In addition, the replacement of copperpoor sulfides by more copper-rich minerals is a characteristic feature of the mineralization. Schmandt et al. (2013) suggested that the Mwashya Subgroup siliciclastic rocks formed the aquifer for the mineralizing fluids and that zoning starts at the base of the Grand Conglomérat. The distribution and relative timing of the copper minerals and of the different alteration types completely coincides with the results of the reactive transport model applied for the stratiform deposits in the Mines Subgroup. Therefore, we suggest that taking into account specific differences in the lithologies and ore minerals, the model proposed here can be applied to other stratiform copper deposits worldwide.

\section{Conclusion}

The paragenesis and distribution of the ore minerals in the main ore deposits in the Mines Subgroup in the Katanga Copperbelt has been simulated by reactive transport models. The numerical models showed the same successive precipitation of chalcopyrite, bornite and chalcocite. Also the distribution of these copper sulfides and pyrite, forming a lateral and vertical halo around the copper sulfides, has been simulated and is related to the continuous supply of copper by the mineralizing fluid. A similar distribution and paragenesis as modelled for the stratiform deposits in the Mines Subgroup has been observed in other mineralization. Therefore we suggest that taking into account specific differences in the lithologies and ore minerals, the model proposed here can be applied to other stratiform copper deposits worldwide. 


\section{Acknowledgements}

We are grateful to Dr. Linda Daniele for sharing her knowledge of the geochemical simulator Retraso and Drs. Thomas Wagner and Bruce Hobbs for valuable feedback and discussions on the thermodynamics and the precipitation reactions of the copper minerals. We would like to thank the two reviewers dr. Sophie Decrée and dr. Fadi Henri Nader for their careful reviews and dr. Annick Anceau for the editorial handling.

\section{References}

Annels, A.E., 1974. Some aspects of stratiform ore deposits of the Zambian Copperbelt and their genetic significance. In Bartholomé, P. (ed.), Gisements stratiformes et provinces cuprifères. Société Géologique de Belgique, Liège, 235-254.

Annels, A.E., 1989. Ore genesis in the Zambian Copperbelt, with particular reference to the northern sector of the Chambishi Basin. In Boyle, R.W., Brown, A.C., Jefferson, C.W., Jowett, E.C. \& Kirkham, R.V. (eds), Sediment-hosted stratiform copper deposits. Geological Association of Canada Special Paper, 36, 427-452.

Bartholomé, P., 1963. Sur la zonalité dans les gisements du Copperbelt de 1'Afrique Centrale. In Symposium on problems of postmagmatic ore deposition, Prague, 1, 317-321.

Bartholomé, P., Evrard, P., Katekesha, F., Lopez-Ruiz, J., Ngongo, M., 1972. Diagenetic ore-forming processes at Kamoto, Katanga, Republic of the Congo. In Amstutz, G.C. \& Bernard, A.J. (eds), Ores in sediments. Springer-Verlag, Berlin, 21-41.

Broughton, D. \& Rogers, T., 2010. Discovery of the Kamoa copper deposit, Central African Copperbelt, D.R.C. Society of Economic Geologists Special Publication, 15, 287-298.

Cailteux, J., 1978. La succession stratigraphique du C.M.N. (ou R.2.3) au centre de la sous-province cuprifère shabienne. Annales de la Société Géologique de Belgique, 100, 73-85.

Cailteux, J., 1994. Lithostratigraphy of the Neoproterozoic Shaba-type (Zaire) Roan Supergroup and metallogenesis of associated stratiform mineralization. Journal of African Earth Sciences, 19, 279-301.

Cailteux, J.L.H., Kampunzu, A.B., Lerouge, C., Kaputo, A.K. \& Milesi, J.P., 2005. Genesis of sediment-hosted stratiform copper-cobalt deposits, central African Copperbelt. Journal of African Earth Sciences, 42, 134-158.

Corbella, M., Ayora, C., Cardellach, E., 2004. Hydrothermal mixing, carbonate dissolution and sulfide precipitation in Mississippi Valleytype deposits. Mineralium Deposita, 39, 344-357.

Decrée, S., Deloule, E., Ruffet, G., Dewaele, S., Mees, F., Marignac, C., Yans, J. \& De Putter, T., 2010. Geodynamic and climate controls in the formation of Mio-Pliocene world-class oxidized cobalt and manganese ores in the Katanga province, DR Congo. Mineralium Deposita, 45, 621-629.

De Putter, T., Mees, F., Decrée, S. \& Dewaele, S., 2010. Malachite, an indicator of major Pliocene $\mathrm{Cu}$ remobilization in a karstic environment (Katanga, Democratic Republic of Congo). Ore Geology Reviews, 38, 90-100.

Dewaele, S., Muchez, Ph., Vets, J., Fernandez-Alonzo, M. \& Tack, L., 2006. Multiphase origin of the $\mathrm{Cu}-\mathrm{Co}$ ore deposits in the western part of the Lufilian fold-and-thrust belt, Katanga (Democratic Republic of Congo). Journal of African Earth Sciences, 46, 455-469.

El Desouky, H.A., Muchez, Ph. \& Cailteux, J., 2009. Two Cu-Co sulfide phases and contrasting fluid systems in the Katanga Copperbelt, Democratic Republic of Congo. Ore Geology Reviews, 36, 315-332.

El Desouky, H.A., Muchez, Ph., Boyce, A.J., Schneider, J., Cailteux, J.L.H., Dewaele, S. \& von Quadt, A., 2010. Genesis of sedimenthosted stratiform copper-cobalt mineralization at Luiswishi and Kamoto, Katanga Copperbelt (Democratic Republic of Congo). Mineralium Deposita, 45, 735-763.

Fay, I. \& Barton, M.D., 2012. Alteration and ore distribution in the Proterozoic Mines Series, Tenke-Fungurume $\mathrm{Cu}-\mathrm{Co}$ district, Democratic Republic of Congo. Mineralium Deposita, 47, 1-19.

François, A., 1973. L'extrémité occidentale de l'arc cuprifère shabien - Etude géologique. Mémoire du Département géologique de la Gécamines, Likasi, République du Zaïre.
Garlick, W.G., 1961. Chambishi. In Mendelsohn, F. (ed.), The Geology of the Northern Rhodesian Copperbelt. MacDonald, London, 281-297.

Hitzman, M.W., Selley, D. \& Bull, S., 2010. Formation of sedimentary rock-hosted stratiform copper deposits through Earth History. Economic Geology, 105, 627-639.

Lee-Potter, J.B., 1961. Baluba. In Mendelsohn, F. (ed.), The Geology of the Northern Rhodesian Copperbelt. MacDonald, London, 343-351.

Lefebvre, J.-J., 1989. Depositional environment of copper-cobalt mineralization in the Katangan sediments of southeast Shaba, Zaire. In Boyle, R.W., Brown, A.C., Jefferson, C.W., Jowett, E.C. \& Kirkham, R.V. (eds), Sediment-hosted stratiform copper deposits. Geological Association of Canada Special Paper, 36, 401-426.

McKinnon, D.M. \& Smit, N.J., 1961. Nchanga. In Mendelsohn, F. (ed.), The Geology of the Northern Rhodesian Copperbelt. MacDonald, London, 234-275.

Muchez, Ph. \& Corbella, M., 2012. Factors controlling the precipitation of copper and cobalt minerals in sediment-hosted ore deposits: Advances and restrictions. Journal of Geochemical Exploration, 118, 38-46.

Muchez, Ph., Vanderhaeghen, P., El Desouky, H., Schneider, J., Boyce, A., Dewaele, S. \& Cailteux, J., 2008. Anhydrite pseudomorphs and the origin of stratiform $\mathrm{Cu}-\mathrm{Co}$ ores in the Katanga Copperbelt (Democratic Republic of Congo). Mineralium Deposita, 43, 575-589.

Muchez, Ph., André-Mayer, A.-S., El Desouky, H.A. \& Reisberg, L., 2015. Diagenetic origin of the stratiform Cu-Co deposit at Kamoto in the Central African Copperbelt. Mineralium Deposita, 50, 437-447.

Oosterbosch, R., 1962. Les minéralisations dans le système de Roan au Katanga. In Lombard, J. \& Nicolini, P. (eds), Gisements stratiformes de cuivre en Afrique. Partie 1, Lithologie - sédimentologie. Association des Services Géologiques Africains, Paris, 71-136.

Oosterbosch, R. \& Schuiling, H., 1951. Copper mineralization in the Fungureme region, Katanga. Economic Geology, 46, 121-148.

Parkhurst, D.L. \& Appelo, C.A.J., 1999. User's guide to PHREEQC (Version 2)-A computer program for speciation, batch-reaction, one-dimensional transport, and inverse geochemical calculations. Denver, U.S. Geological Survey Water-Resources Investigations Report 99-4259, 1-310.

Saaltink, M.W., Ayora, C. \& Carrera, J., 1998. A mathematical formulation for reactive transport that eliminates mineral concentrations. Water Resources Research, 34, 1649-1656.

Schmandt, D., Broughton, D., Hitzman, M.W., Plink-Bjorklund, P., Edwards, D. \& Humphrey, J., 2013. The Kamoa copper deposit, Democratic Republic of Congo: Stratigraphy, diagenetic and hydrothermal alteration, and mineralization. Economic Geology, $108,1301-1324$.

Schuh, W., Leveille, R., Fay, I. \& North, R., 2012. Geology of the TenkeFungurume sediment-hosted strata-bound copper-cobalt district, Katanga, Democratic Republic of Congo. Society of Economic Geologists Special Publication, 16, 269-301.

Selley, D., Broughton, D., Scott, R., Hitzman, M., Bull, S., Large, R., McGoldrick, P., Croaker, M., Pollington, N. \& Barra, F., 2005. A new look at the geology of the Zambian Copperbelt. In Hedenquist, J.W., Thompson, J.F.H., Goldfarb, R.J. \& Richards, J.P. (eds), Economic Geology $100^{\text {th }}$ Anniversary Volume. Society of Economic Geologists, Littleton (CO), 965-1000.

Van Langendonck, S., Muchez, Ph., Dewaele, S., Kaputo Kalubi, A. \& Cailteux, J., 2013. Petrographic and mineralogical study of the sediment-hosted $\mathrm{Cu}-\mathrm{Co}$ ore deposit at Kambove West in the central part of the Katanga Copperbelt (DRC). Geologica Belgica, 16, 91104.

Wolery, T.J., 1992. EQ3/6, A Software Package for Geochemical Modeling of Aqueous Systems: Package Overview and Installation Guide (Version 7.0). Publ. UCRL-MA-110662 PT I, Lawrence Livermore Lab., Livermore California.

Manuscript received 02.12.2015, accepted in revised form 13.05.2016, available on line 25.05.2016. 